\title{
Analyzing Students' Higher Order Thinking Skills Using TIMSS-Like Questions
}

\author{
E Gradini $^{1}$, NA Lubis ${ }^{2}$, Firmansyah $^{3}$, B Yustinaningrum ${ }^{4}$, and R Gemasih ${ }^{5}$ \\ \{ egagradini, firmansyahb, bettryyustinanningrum,nurainunlubis\}@stain-gp.ac.id \\ Mathematics Education Departement, STAIN Gajah Putih Takengon, Jalan Yos Sudarso no. 10 Takengon, \\ Indonesia ${ }^{1,2,3,4,5}$
}

\begin{abstract}
This study aims to assess students' ability in solving Higher Order Thinking Skill (HOTS) problems. Test from national examination, formative and summative test, and also the test written in high school Mathematics textbook commonly used were analyzed, and it found that most of the test are to measure the lower order thinking skills. In 2018, Higher Order Thinking Skill (HOTS) problems emerged in National Examination and bring the nation in polemic about how mathematics classroom should be conducted. This study assess students' abilities in analyzing, generalizing, integrating, justifying, and nonroutine problem solving using TIMSS questions. Qualitative method was used as the research approach in this study. The finding showed TIMSS Questions still challenging to students. The findings showed none of the students perceived their thinking skills' levels at "high". 59 students $(78.67 \%)$ perceived their Higher Order Thinking skills' level at "moderate", while 16 students $(21.33 \%)$ perceived their Higher Order Thinking skills' level at "low". 78.67\% students at "moderate" level has the ability to apply their understanding and knowledge in situation relatively complex.
\end{abstract}

Keywords: HOTS, Thinking, TIMSS, Higher Order, Bloom Taxonomy

\section{Introduction}

The Ujian Nasional Berbasis Komputer (UNBK), computer-based national examination in Indonesia, for the Senior High Schoolhas been held on April 2-5 and April 9-12, 2018. Unlike previous years, the UNBKintroduced Higher Order Thinking Ability Thinking Skills (HOTS) problems. The number of problems reaches $10 \%$ for Junior High School and 15\% for Senior High School. The Ministry of Education and Culture of Indonesia,ensures that HOTS problems will be re-used in 2019 with $20 \%$ number of problems (Zunita, 2018).

The implementation of HOTS on UNBK, especially on mathematicswas felt to be too difficult for students. It received a lot of responses from test participants and became viral on social media that makes the KomisiPerlinduganAnak Indonesia (KPAI) criticized the Ministry of Education and Culture's policies (Noor, 2018). In fact, the policy of applying the HOTS model is intended to train children to think critically, creatively, and analytically. This policy in line with the goals ofThe Kurikulum 2013 that stated to improve students' reasoning, including critical and analytical thinking.

BambangSuryadi, Chairperson of the National Education Standards Agency (BSNP) in his presentation said that it had been the policy of the Ministry of Education and Culture to apply mathematical problems that encourage students to do reasoning, not just understanding and applying. Furthermore, the Indonesian National Assessment is directed to an assessment model that requires thinking skills that not only recall, restate, or refer without processing (recite). However, there are HOTS principles that have not been fully implemented in preparing exam questions. In addition, teachers and students are not used to working on HOTS problems even though the problem have long appeared in Mathematics textbooks in schools. Therefore, the application of the HOTS problems in the UN needs to be balanced with an increase in the ability of teachers and students in the teaching and learning process. There have been some training in the preparation of HOTS problems but not regularly and involving many mathematics teachers, especially mathematics teachers in Madrasahs.

In order to encourage the development of the HOTS model, scoring of the questions is done by considering the complexity of the problem. More complex questions are given a higher weight. Thus, there will be distinguishing factors between students who are able to answer the HOTS problems and students who are only 
able to answer easy or moderate problems. So that it is necessary to align the learning process and assessment with reference to national education standards.

There are a number of international tests that are used to evaluating education globally and are also used to find out whether Indonesia is able to compete with countries in the world, and where Indonesia's position is among countries in the world. Two of them are the Program for International Student Assessment (PISA) and Trends in the International Mathematics and Science Study (TIMSS). In this paper, we used TIMSS-like question to analyze the level of students Higher Order Thinking Skill (HOTS). This study aims to assess students' ability in solving Higher Order Thinking Skill (HOTS) problems. Students' abilities in analyzing, generalizing, integrating, justifying, and non-routine problem solving assessed using the TIMSS-like questions.

\section{Literature Review}

\subsection{Higher Order Thinking Skills}

Higher Order Thinking Skills (HOTS) are one of the components that are emphasized in the Kurikulum 2013 beside STEM (Science, Technology, Engineering, Mathematics)and 4C (Communication; Collaboration; Critical Thinking and Problem Solving; Creativity and Innovation). However, the implementation is limited to fulfilling the demands of the 2013 Curriculum. Both teachers and students feel that applying HOTS in learning mathematics in schools are challenging. According to Heong (2011), HOTS combines the ability of creative thinking and critical thinking.

Mathematics is a science related to abstract concepts, therefore the presentation of mathematical material in learning is often associated with everyday life with the aim that students are able to find concepts and develop their mathematical abilities based on the experience or knowledge that students have. Students are said to be able to solve a problem if the student is able to examine a problem and be able to use his knowledge into a new situation. This ability is usually known as Higher Order Thinking Skills.

Higher Order Thinking Skills (HOTS) are students' thinking processes at a higher cognitive level which are developed from various cognitive concepts and methods and taxonomy of learning such as; problem-solving methods, taxonomy, and taxonomy of learning, teaching, and assessment. Krulik and Rudnick (1999) explained that HOTS includes the ability to solve problems, the ability to think creatively, think critically, the ability to argue, and the ability to make decisions. While Krathwohl (2002) gives the definition of HOTS as the ability to connect, manipulate, and change the knowledge and experience that has been possessed critically and creatively in determining decisions to solve problems in new situations. Table 1 showed basic concepts of Higher Order Thinking Skill (HOTS) and table 2 showed various meaning on these past year.

Brookhart (also reinforces the above statement stating that HOTS includes logic and reasoning, analysis, evaluation, problem solving, and decision making (judgment). Krathwohl(2002) classifies that judgment is included in the level of evaluation.

In conclusion HOTS is the ability to analyze, evaluate and create in solving problems. Analytical ability can be interpreted as an individual's ability to determine parts of a problem and show the relationship between parts, see the causes of an event or give arguments that support a statement. Evaluation ability is an activity to make judgments regarding the value of an idea, creation, method or method. Creative ability is the ability to combine elements to form a new and unique structure, design ways, and find multiple solutions. Reasoning is a thought process in determining a conclusion from a new knowledge that is received by linking it with the knowledge that has been previously owned. Reasoning is needed in the process of thinking and drawing conclusions in the form of knowledge.

HOTS in mathematics leads formulate, employ, and interpret. These three words describe the process that students must do to connect the context with mathematics and solve it. The capabilities that underlie this mathematical process include communication, mathematics, representation, reasoning and argumentation, formulating strategies to solve problems, using symbolic language, formal, and techniques and operations, using mathematical tools. 
Tabel 1. Basic Concept of Higher Order Thinking Skills

\begin{tabular}{|c|c|c|c|c|}
\hline $\begin{array}{l}\text { Problem Solving } \\
\text { (Krulik\& } \\
\text { Rudnick) }\end{array}$ & $\begin{array}{l}\text { Taksonomi Kognitif } \\
\text { Bloom Original }\end{array}$ & $\begin{array}{l}\text { Taksonomi } \\
\text { Revisi } \\
\text { (Anderson } \\
\text { \&Krathwohl) }\end{array}$ & Bloom & $\begin{array}{l}\text { Higher } \\
\text { Order } \\
\text { Thinking } \\
\text { Skill } \\
\end{array}$ \\
\hline Recall Basic & $\begin{array}{l}\text { Knowledge } \\
\text { Comprehense } \\
\text { Application }\end{array}$ & $\begin{array}{l}\text { Remember } \\
\text { Understand } \\
\text { Apply }\end{array}$ & & \\
\hline Critical & Analysis & Analyze & & $\begin{array}{l}\text { Critical } \\
\text { Thinking }\end{array}$ \\
\hline \multirow[t]{2}{*}{ Creative } & Synthesis & Evaluate & & $\begin{array}{l}\text { Creative } \\
\text { thinking }\end{array}$ \\
\hline & Evaluation & Create & & $\begin{array}{l}\text { Problem } \\
\text { Solving } \\
\text { Decision } \\
\text { Making }\end{array}$ \\
\hline
\end{tabular}

Table 2.Various Meaning of HOTS

\begin{tabular}{|c|c|c|}
\hline Sumber & Tahun & Definisi \\
\hline King et al. & 1998 & $\begin{array}{l}\text { "includes critical, logical, reflective, metacognitive, and creative thinking. Activated } \\
\text { when individuals face unknown problems, uncertainties, questions, or dilemmas." }\end{array}$ \\
\hline NCTM & 2000 & "Solving Routine Problems" \\
\hline $\begin{array}{l}\text { Anderson } \quad \text { and } \\
\text { Krathwohl }\end{array}$ & 2001 & Processing -Analyze, Evaluation, \\
\hline $\begin{array}{l}\text { Lopez and } \\
\text { Whittington }\end{array}$ & 2001 & $\begin{array}{l}\text { "(it) happens when someone picks up new information and information stored in } \\
\text { memory and relates to and / or rearranges and expands this information to reach a } \\
\text { goal or find answers that might be in a confusing situation." }\end{array}$ \\
\hline Weiss, E. & 2003 & Collaborative, authentic, unstructured, challenging problems \\
\hline Miriet al. & 2007 & $\begin{array}{l}\text { "...Strategy - meta-objective setting; while critical, systemic, and creative thinking } \\
\text { are tactics - activities needed to achieve the stated goals." }\end{array}$ \\
\hline Rajendran, N. & 2008 & The use of an expanded mind to face new challenges. \\
\hline Thompson, $\mathrm{T}$. & 2008 & "Non-Algorithmic Thinking" \\
\hline $\begin{array}{l}\text { Thomas, A. and } \\
\text { Thorne, G. }\end{array}$ & 2010 & $\begin{array}{l}\text { "... (It) requires thinking to a higher level than just restating the facts. (It) requires } \\
\text { that we do something with facts. We must understand them, connect them with each } \\
\text { other, categorize them, manipulate them, integrate them in new or new ways, and } \\
\text { apply them when we seek new solutions to new problems." }\end{array}$ \\
\hline Kruger, K. & 2013 & $\begin{array}{l}\text { "involves"concept formation, critical thinking, creativity/ brainstorming, problem } \\
\text { solving, mental representation, use of rules, reasoning, and logical thinking }\end{array}$ \\
\hline
\end{tabular}




\subsection{Trends In Mathematics And Science Study}

The assessment of mathematics and science achievements in TIMSS is categorized into two domains; the content and cognitive domain by considering the curriculum that concerned in the country. The distribution of specifications and assessments is as follows:

\subsubsection{Contents Domain.}

Content consists of four domains: numbers, algebra, geometry, data and opportunities. Each domain of content is detailed in several topics. For example, the domain of number content includes the topic of fractions and decimals, integers, ratios, proportions and percentages. Table 3 shows the proportion of abilities tested in each domain that is assessed on the content dimension.

Table 3. Proportion of Abilities Tested in Content Domain

\begin{tabular}{ccc}
\hline Domain & Proportion & \multicolumn{1}{c}{ Topic } \\
\hline Number & $30 \%$ & Positive Integers \\
\cline { 3 - 3 } & & Fraction, Decimal, and Integer \\
\cline { 3 - 3 } & $30 \%$ & Ratio, Proportion, Percentage \\
& & Algebraic Expression and operation \\
& & Equation and Inequation \\
\hline Geometry & $20 \%$ & Reometric Shape \\
\hline Data & $20 \%$ & Measurement \\
\hline & & Characteristic of Data \\
\hline
\end{tabular}

\subsubsection{Cognitive Domain}

Cognitive dimension consists of three domains; knowing, applying, and reasoning. Cognitive dimensions are defined as the expected behavior of students when they are dealing with a mathematical domain that is included in the dimension of content. Table 4 shows the proportion of abilities tested on the cognitive dimensions in the 2015 TIMSS study.

According to taxonomy bloom, the level of high-level thinking ability lies at the level of analyzing (C4), evaluating (C5), and creating (C6). Bloom states that there are two levels of students' mathematical thinking; Lower Order Thinking Skills (LOTS) and Higher Order Thinking Skills (HOTS). Then it can be classified as ability level according to TIMSS and Bloom Taxonomy. 
Table 4. Proportion of abilities tested in cognitive domain

\begin{tabular}{|c|c|c|}
\hline Domain & Proportion & Topic \\
\hline \multirow[t]{5}{*}{ Knowing } & $35 \%$ & Recall \\
\hline & & Recognize \\
\hline & & Classify/Order \\
\hline & & Compute \\
\hline & & Retrieve \\
\hline \multirow[t]{3}{*}{ Applying } & $40 \%$ & Determine \\
\hline & & Represent/ Model \\
\hline & & Implement \\
\hline \multirow[t]{2}{*}{ Reasoning } & $25 \%$ & Analyze \\
\hline & & Integrate/Synthesize \\
\hline \multirow[t]{4}{*}{ Data } & $20 \%$ & Evaluate \\
\hline & & Draw \\
\hline & & Generalize \\
\hline & & Justify \\
\hline
\end{tabular}

Table 5. Relationship between Bloom Taxonomy, TIMSS, and HOTS

\begin{tabular}{llll}
\hline \multicolumn{1}{c}{ Bloom Taxonomy } & \multicolumn{1}{c}{ Level TIMSS } & $\begin{array}{c}\text { Level of } \\
\text { Thinking Skill }\end{array}$ \\
\hline C6 & Level Advance & \\
\hline $\begin{array}{l}\text { The ability to combine elements } \\
\text { into something new, complete }\end{array}$ & $\begin{array}{l}\text { The ability to give reasons, draw } \\
\text { conclusions, make generalizations, and }\end{array}$ & \\
$\begin{array}{l}\text { and broad, or make something } \\
\text { original }\end{array}$ & $\begin{array}{l}\text { solve linear equations. Students can } \\
\text { complete various fractions, proportions } \\
\text { and percent problems and justify their }\end{array}$ & Higher Order \\
conclusions. Students can express & Thinking Skills \\
C5 & $\begin{array}{l}\text { algebraic generalizations and model } \\
\text { situations. }\end{array}$ & (HOTS) \\
The ability to determine a degree \\
based on certain norms, criteria \\
or benchmarks & $\begin{array}{l}\text { The ability to solve various problems } \\
\text { involving equations, formulas and }\end{array}$ & \\
& functions. & & \\
& The ability to give reasons with & \\
geometry figures to solve problems. The & & \\
\hline
\end{tabular}




\begin{tabular}{|c|c|c|}
\hline Bloom Taxonomy & Level TIMSS & $\begin{array}{c}\text { Level of } \\
\text { Thinking Skill } \\
\end{array}$ \\
\hline & $\begin{array}{l}\text { ability to give reasons with data from } \\
\text { several sources or unusual } \\
\text { representations to solve problems with } \\
\text { many steps. }\end{array}$ & \\
\hline C4 & Level High & \\
\hline $\begin{array}{l}\text { The ability to separate concepts } \\
\text { into several components and } \\
\text { connect with each other to gain } \\
\text { an understanding of the concept } \\
\text { as a whole }\end{array}$ & $\begin{array}{l}\text { The ability to apply their understanding } \\
\text { and knowledge in situation relatively } \\
\text { complex. Students can use information } \\
\text { fromseveral sources for solving } \\
\text { problems involving } \\
\text { typenumbers and operations. } \\
\text { The ability to change the form of } \\
\text { ordinary fractions into decimal and } \\
\text { percent forms or vice versa. } \\
\text { The ability to show basic procedural } \\
\text { knowledge related to expression algebra. } \\
\text { The ability to use line, angle, shape and } \\
\text { space to solve problems and analyze } \\
\text { data. }\end{array}$ & \\
\hline C3 & Level Intermediate & \\
\hline $\begin{array}{l}\text { Ability to do something and } \\
\text { apply concepts in certain } \\
\text { situations }\end{array}$ & $\begin{array}{l}\text { The ability to apply basic mathematical } \\
\text { knowledge in a variety situation. } \\
\text { Students can solve problems involving } \\
\text { decimals, fractions, proportion and } \\
\text { percentage, and simple algebraic } \\
\text { relationships. } \\
\text { The ability to make two-dimensional } \\
\text { image connections to three-dimensional } \\
\text { objects. } \\
\text { The ability to read, interpret, and create } \\
\text { charts and tables. }\end{array}$ & $\begin{array}{l}\text { Lower Order } \\
\text { Thinking Skills } \\
\text { (LOTS) }\end{array}$ \\
\hline C2 & Level Low & \\
\hline $\begin{array}{l}\text { Ability to understand instructions } \\
\text { and affirm ideas or concepts that } \\
\text { have been taught }\end{array}$ & \multirow[t]{3}{*}{$\begin{array}{l}\text { Students have knowledge of integers } \\
\text { and decimals, basic calculations and } \\
\text { graphs. }\end{array}$} & \\
\hline C1 & & \\
\hline $\begin{array}{l}\text { The ability to recall information } \\
\text { stored in memory }\end{array}$ & & \\
\hline
\end{tabular}

\section{Research Method}

This study is a survey research where data collected directly from respondents. The data was collected at MAN 1 Takengon, MAN 2 Takengon, and MAN 3 Takengon. The population was the $10^{\text {th }}$-grade students in Aceh Tengah, Aceh. The students had to be representation of (1)Gender, (2)Level of Achievement, (3) Age $\leq 15$ years old.

20 TIMSS-like questions were given to 75 students. These questions are designed so that both dimensions of assessment; content and cognitive can be observed. The form of questions in TIMSS is multiple choice with 4 answer choices, short entries and descriptions. Short entries and descriptions are often called "constructed responses". If students answered the 
question correctly, they given a score of 2 , and if answered incorrectly given a score of 1 , and 0 if no answer.

The TIMSS score then assessed based on students ability in analysis, evaluation, and creation (Anderson, 2001). Categorizing and analyzing the level of Higher Order Thinking Skills is the main target of this study.Then, students' answers were analyzed based on Level of HOTS by Anderson and Kratwohl (2011). The HOTS level then categorized as follow:

Table 6. Category of HOTS Level

\begin{tabular}{cc}
\hline Mean Score & Level \\
\hline $0.00-1.00$ & Low \\
\hline $1.01-1.50$ & Moderate \\
\hline $1.51-2.00$ & High \\
\hline
\end{tabular}

\section{Research Finding}

The level of students' Higher Order Thinking Skills (HOTS) were carried out by giving HOTS test questions taken from the questions tested on TIMSS in 2015. The test assessed cognitive domain of each content; number, algebra, geometry, and data and chance. There are $29.37 \%$ students who answer the test correctly, $63.93 \%$ students have wrong answer, and $6.33 \%$ did not answer the test. Percentage of students that answer TIMSS-like questions were given on table 7.

Table 7. Percentage of students that answer TIMSS- like questions

\begin{tabular}{|cccc|}
$\begin{array}{c}\text { Correct } \\
\text { Answer }\end{array}$ & $\begin{array}{c}\text { Wrong } \\
\text { Answer }\end{array}$ & $\begin{array}{c}\text { No } \\
\text { Answ } \\
\text { er }\end{array}$ \\
$\begin{array}{c}\text { MAN 1 } \\
\text { Takengon }\end{array}$ & $27.80 \%$ & $65.00 \%$ & $7.20 \%$ \\
\hline $\begin{array}{c}\text { MAN 2 } \\
\text { Takengon }\end{array}$ & $34.20 \%$ & $55.60 \%$ & $\begin{array}{c}10.20 \\
\%\end{array}$ \\
\hline $\begin{array}{c}\text { MAN 3 } \\
\text { Takengon }\end{array}$ & $27.20 \%$ & $71.20 \%$ & $1.60 \%$ \\
\hline Average & $29.73 \%$ & $63.93 \%$ & $6.33 \%$ \\
\hline
\end{tabular}

The findings showed none of the studentsperceived their thinking skills' levels at "high". 59 students (78.67\%) perceived their Higher Order Thinking skills' level at "moderate", while 16 students $(21.33 \%)$ perceived their Higher Order Thinking skills' level at "low".78.67\% students at "moderate" level has the ability to apply their understanding and knowledge in situation relatively complex. They able to use information from several sources for solving problems involving various type numbers and operations. They also have the ability to change the form of ordinary fractions into decimal and percentage forms or vice versa. Meanwhile, 16 students at "low" level able to apply basic mathematical knowledge in a variety situation. Students can solve problems involving decimals, fractions, proportion and percentage, and simple algebraic relationships. The students have the ability to make two-dimensional image connections to three-dimensional objects and the ability to read, interpret, and creats and 
tables.

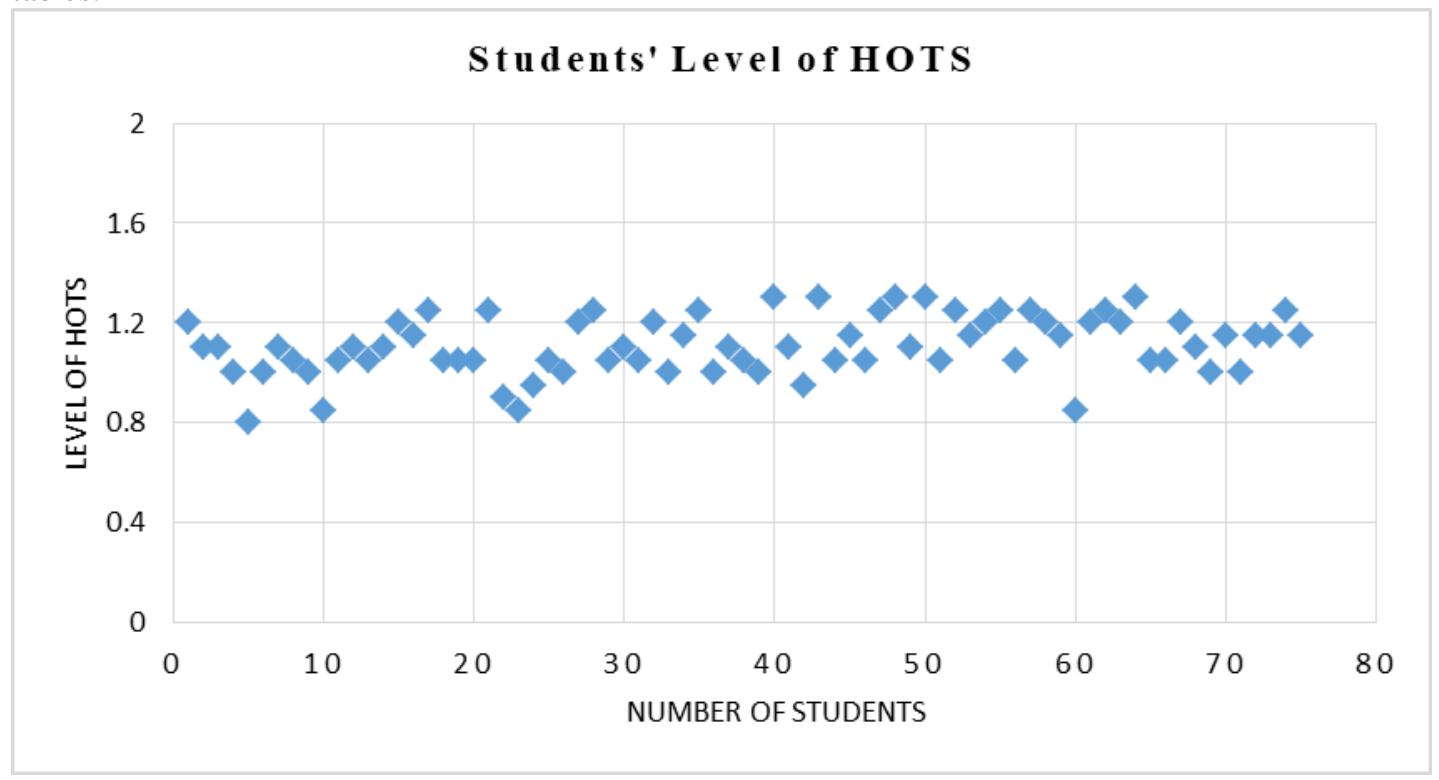

Fig .1. Grafic student's Level of HOTS

Table 8. Students' level of HOTS based on the Domain

\begin{tabular}{ccccccccc}
\hline $\begin{array}{c}\text { Level of } \\
\text { HOTS }\end{array}$ & \multicolumn{2}{c}{ Number } & \multicolumn{2}{c}{ Algebra } & \multicolumn{2}{c}{ Geometry } & \multicolumn{2}{c}{ Data and Chance } \\
Low & 23 & $30.67 \%$ & 49 & $65.33 \%$ & 42 & $56.00 \%$ & 49 & $65.33 \%$ \\
Moderate & 47 & $62.67 \%$ & 24 & $32.00 \%$ & 18 & $24.00 \%$ & 21 & $28.00 \%$ \\
High & 5 & $6.67 \%$ & 2 & $2.67 \%$ & 15 & $20.00 \%$ & 5 & $6.67 \%$ \\
\hline
\end{tabular}

Table 8 showed that students feel that Algebra, geometry and Data and Change is still challenging. 65.33\% students at "Low" level at Algebra, 56\% students at "Low" level at Geometry, and $65.33 \%$ students. Number seems to be the least challenging content for students by having 30.67\% "Low" level students. Surprisingly, on Geometry content, there are $20 \%$ students at "high" level. It means they are able to give reasons with geometry figures to solve problems and to use line, angle, shape, and space to solve problems and analyze data.

\section{References}

[1]Anderson, L. W., \&Krathwohl, D. R. 2010. Kerangka Landasan untuk Pembelajaran, Pengajaran, dan Asesmen. Yogyakarta: Pustaka Pelajar.

[2]Brookhart,M. 2010.How to Assess Higher-Order Thinking Skills in Your Classroom, ASCD, Alexandria, Virginia

[3]Heong, Y.,Othman, W., Yunos, J., et all. The Level of Marzano Higher Order Thinking Skill among Technical Education Students. International Journal of Science and Humanity, Vol 1, No 2, July 2011

[4]King, F.J., Goodson, L., and Rohani, F. (1998) Higher-Order Thinking Skills: Definitions, Strategies, and Assessment. URL: http://www.cala.fsu.edu/files/higher_order thinking_skills.pdf. 
[5]Krathwohl, D. R. 2002. A revision of Bloom's taxonomy: An overview. Theory into practice 4

[6]Kruger, K. (2013) Higher-Order Thinking. Hidden Sparks, Inc. New York, New York. [7]Anderson, L., and Krathwohl, D. (eds.) (2001). A Taxonomy for Learning, Teaching, and Assessing: A Revision of Bloom's Taxonomy of Educational Objectives. Longman Publishing Co., New York, New York.

[8]Krulik, S., \& Rudnick, J. A. 1999. Innovative Tasks to Improve Critical and Creative Thinking Skills. Developing Mathematical reasoning in Grades K-12, 138-145.

[9]Lopez, J., and Whittington, M. (2001). Higher-Order Thinking in a College Course: A Case Study. Proceedingsof the Annual NACTA Conference, Lincoln, Nebraska, pp. 22-29. [10]Noor, A. 2018. Soal UNBK MatematikaSulit, KPAI AngkatBicara. Online. Accessed on September 4, 2018, retrieved fromhttps://www.viva.co.id/gayahidup/parenting/1027734-soal-unbk-matematika-sulit-kpai-angkat-bicara

[11]Puspita, R. 2018. Nilai rata -rata UN Menurun. online. Diakses pada 3 Juni 2018 melalui https://www.republika.co.id/berita/pendidikan/eduaction/18/05/24/p96xrf428mendikbud-nilai-rata-rata-un-turun

[12]Rajendran,N.2008. Teaching and Acquiring Higher Order Thinking Skills: Theory and Practice. Sultan Idris Education University. TanjungMalim, Malaysia.

[13]Thompson, T.2008. Mathematics Teacher Interpretation of Higher Order Thinking Skills in BloomsTaxonomy. International Electronic Journal of Mathematics Education, Vol. 3, No. 2, pp. 96-109

[14]Weiss, E.2003. Problem-Based Learning in the Information Age: Designing Problems to Promote Higher Order Thinking Skills. Wiley Periodicals, Vol 95,pp.25-31

[15]Zunita, Ap. 2018. Hardiknas 2018: Pendidikan Indonesia ButuhPenguatan HOTS.

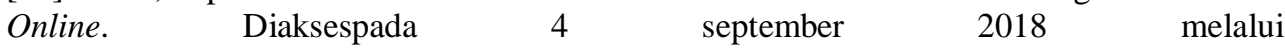
https://www.kemdikbud.go.id/main/blog/2018/05/hardiknas-2018-pendidikan-indonesiabutuh-penguatan-high-order-thinking-skills 